\title{
Ingensalinae subfam. nov. (Hemiptera: Fulgoromorpha: Fulgoroidea: Inoderbidae), a new planthopper subfamily from mid-Cretaceous Kachin amber from Myanmar
}

\author{
Cihang Luo ${ }^{1,2}$, Zhishun Song ${ }^{3}$, Xiaojing Liu ${ }^{1,4}$, Tian Jiang ${ }^{5}$, Edmund A. Jarzembowski ${ }^{1}$, and Jacek Szwedo ${ }^{6}$ \\ ${ }^{1}$ State Key Laboratory of Palaeobiology and Stratigraphy, Nanjing Institute of Geology and Palaeontology and Center for \\ Excellence in Life and Paleoenvironment, Chinese Academy of Sciences, 39 East Beijing Road, Nanjing 210008, China \\ ${ }^{2}$ University of Chinese Academy of Sciences, Beijing 100049, China \\ ${ }^{3}$ Institute of Insect Resources and Biodiversity, School of Life Sciences, Chemistry \& Chemical Engineering, \\ Jiangsu Second Normal University, Nanjing 210013, China \\ ${ }^{4}$ School of GeoSciences, Yangtze University, Wuhan, Hubei 430100, China \\ ${ }^{5}$ State Key Laboratory of Biogeology and Environmental Geology, China University of Geosciences (Beijing), \\ Beijing 100083, China \\ ${ }^{6}$ Laboratory of Evolutionary Entomology and Museum of Amber Inclusions, Department of Invertebrate Zoology and \\ Parasitology, Faculty of Biology, University of Gdańsk, 59, Wita Stwosza Street, 80-308 Gdańsk, Poland
}

Correspondence: Cihang Luo (chluo@nigpas.ac.cn)

Received: 13 October 2021 - Revised: 6 December 2021 - Accepted: 7 December 2021 - Published: 5 January 2022

\begin{abstract}
The second genus and species of recently established planthopper family Inoderbidae, Ingensala xiai gen. et sp. nov., is described based on a well-preserved specimen from mid-Cretaceous Kachin (Burmese) amber, and it can be definitely attributed to Inoderbidae mainly based on its head structure, pronotum, and mesonotum without median and lateral carinae and tegmen venation. Ingensala gen. nov. is superficially similar to Eofulgoridium regarding its venation pattern, rather than to the Inoderbidae type genus Inoderbe, and further confirmed that Inoderbidae might descend from the Jurassic planthopper family Fulgoridiidae. The early fork of $\mathrm{CuA}$ and the stem $\mathrm{CuA}$ bearing many branches also can be found in Jurassic Qiyangiricaniidae and Eocene Weiwoboidae. Ingensala gen. nov. also superficially resembles some Tropiduchidae: Tropiduchinae. The new genus differs from the type genus Inoderbe to a large extent according to its wide head, frons without fastigium, antennae not so elongate, the tectiform condition of wings' position in repose, large, broad and translucent tegmen, triangular basal cell, single $\mathrm{CuA}_{1}$, legs covered with short setae, and the lack of filamentous wax on body. Therefore, two new subfamilies (Inoderbinae stat. nov. and Ingensalinae subfam. nov.) are established for these two genera respectively. The
\end{abstract}

diversification in planthoppers could be the result of pressure of environmental changes during the mid-Cretaceous, and Inoderbidae provides more information for us to understand the Cretaceous stage of Fulgoroidea evolution and diversification.

\section{Introduction}

The Hemiptera is the fifth largest order among insects and the largest outside the hyperdiverse Holometabola (Grimaldi and Engel, 2005; Szwedo, 2018). The suborder Fulgoromorpha, commonly known as planthoppers, is one of the main groups of hemipterans (Bartlett et al., 2018; Szwedo, 2018), and it contains three superfamilies: the extinct Permian Coleoscytoidea Martynov, 1935, extinct Permo-Triassic Surijokocixioidea Shcherbakov, 2000, and one extant superfamily Fulgoroidea Latreille, 1807, known in the fossil record since the Triassic (Szwedo et al., 2004; Zhang et al., 2021). Although the fossil record of Fulgoromorpha dates back to the Permian, pre-Jurassic Fulgoromorpha were not numerous and diverse (Shcherbakov, 2004). Coleoscytoidea only contains 3 genera and 10 species, and Surijokocixioidea only includes 7 
genera and 8 species (Szwedo et al., 2004; Bourgoin, 2021). The oldest Fulgoroidea are represented by the Triassic family Szeiniidae Zhang, Jiang, Szwedo et Zhang, 2021 (Zhang et al., 2021). Ancestral Fulgoroidea have increased their diversity since the Jurassic (Szwedo, 2010), where most Jurassic planthoppers refer to Fulgoridiidae (Shcherbakov, 2004), a paraphyletic assemblage with over 150 species (Bourgoin and Szwedo, 2008), plus another Jurassic planthopper family, Qiangiricaniidae Szwedo, Wang et Zhang, 2011, including only one genus and species (Szwedo et al., 2011).

The Cretaceous is an important period for the diversification of planthoppers, the fossil record of many extant families making its debut in fossil record at this time, and several extinct families were only discovered in the Cretaceous (Bourgoin, 2021): Dorytocidae Emeljanov et Shcherbakov, 2018 (Emeljanov and Shcherbakov, 2018; Song et al., 2021), Inoderbidae Shcherbakov et Emeljanov, 2021 (Shcherbakov and Emeljanov, 2021), Jubisentidae Zhang, Ren et Yao, 2019 (Zhang et al., 2019), Katlasidae Luo, Jiang et Szwedo, 2020 (Luo et al., 2020), Lalacidae Hamilton, 1990, Mimarachnidae Shcherbakov, 2007a, Neazoniidae Szwedo, 2007, Perforissidae Shcherbakov, 2007b, and Yetkhatidae Song, Szwedo et Bourgoin, 2019 (Song et al., 2019). Three extant families were also confirmed: Achilidae Stål, 1866, Cixiidae Spinola, 1839, and Dictyopharidae Spinola, 1839.

Herein we describe another new planthopper, Ingensala xiai gen. et sp. nov., which represents a new subfamily Ingensalinae subfam. nov., placed in Inoderbidae, from midCretaceous Kachin amber in Myanmar.

\section{Material and methods}

The studied specimen comes from a Cretaceous amber mine, near Danai (Tanai) Town $\left(26^{\circ} 21^{\prime} 33.41^{\prime \prime} \mathrm{N}, 96^{\circ} 43^{\prime} 11.88^{\prime \prime} \mathrm{E}\right.$; palaeolatitude $5.0 \pm 4.7^{\circ} \mathrm{S}$ ) in the Hukawng Valley of Myanmar; see fig. 1 in Jiang et al. (2019) (Kania et al., 2015; Thu and Zaw, 2017; Westerweel et al., 2019). Over the past 100 years, and particularly in the last two decades, Kachin amber has received worldwide scientific interest. More than 600 invertebrates, vertebrates, protists, plants, and fungi families have been reported (Ross, 2021). The amber is giving us new insights into modern faunistic complex development during mid-Cretaceous biotic re-organization (Szwedo and Nel, 2015) and provides significant material to understand the Cretaceous Terrestrial Revolution, marked by the radiation of angiosperms, social insects, and early mammals (Lloyd et al., 2008; Genise et al., 2020; Peris et al., 2020). Radiometric $\mathrm{U}-\mathrm{Pb}$ zircon dating of the volcaniclastic matrix of the amber constrained a refined age of $98.79 \pm 0.62 \mathrm{Ma}$ (earliest Cenomanian) (Shi et al., 2012), which is also supported by the ammonite trapped in the amber (Yu et al., 2019).
The photographs were taken with a Zeiss Stereo Discovery V16 microscope system in the Nanjing Institute of Geology and Palaeontology, Chinese Academy of Sciences, Nanjing, China; measurements were taken using Zen software. Photomicrographic composites of 50 individual focal planes were digitally stacked as obtained using the software Helicon Focus 6.7.1 for a better illustration of 3D structures. Photographs were adjusted using Adobe Lightroom Classic, and line drawings were prepared using CorelDraw 2019 graphic software.

The venational nomenclature follows Bourgoin et al. (2015): CA, costal margin (costa anterior); Pc + CP, precosta + costa posterior; $\mathrm{ScP}+\mathrm{R}$, subcosta posterior + radius; $\mathrm{RA}$, radius anterior; RP, radius posterior; MP, media posterior; $\mathrm{CuA}$, cubitus anterior; $\mathrm{CuP}$, cubitus posterior; $\mathrm{Pcu}$, postcubitus; $A_{1}$, first anal vein; $A_{2}$, second anal vein.

\section{Systematic palaeontology}

Order Hemiptera Linnaeus, 1758

Suborder Fulgoromorpha Evans, 1946

Superfamily Fulgoroidea Latreille, 1807

Family Inoderbidae Shcherbakov et Emeljanov, 2021

\section{Type genus}

Inoderbe Shcherbakov et Emeljanov, 2021; by original designation and monotypy.

Revised diagnosis. Rather small planthoppers, with habitus variable (derbid-like and tropiduchid-like). Lateral carinae of vertex and frons foliaceous, vertex and frons without median carina; fastigium may be developed; clypeus protruded, without median carina but with two lateral carinae. Pronotum with disc elevated, without median carina; postocular carinae may be developed; mesonotum in shape of diamond, with weakened or without distinct median and lateral carinae, mesoscutellum not distinctly separated. Tegmen with clear submarginal pterostigma, costal area wide with several transverse veinlets, not continued with apical cell series; clavus closed; stem MP forked much later than stem $\mathrm{CuA}$ with a few terminal branches (three), stem MP area reduced; stem $\mathrm{CuA}$ forked very early (at same level of fork of $\mathrm{ScP}+\mathrm{R}$ or even earlier), with numerous branches (about six terminals), stem $\mathrm{CuA}$ area large, few crossveins in one gradate series. Hind wing with stems $\mathrm{ScP}+\mathrm{R}, \mathrm{MP}$ and $\mathrm{CuA}$ with a few branches (two or three), costal margin proximally with series of hamuli. Legs long and slender, carinate, metatibia without lateral spine, apical teeth without seta. Female ovipositor short, with three pairs of appendages: gonapophyses VIII, gonapophyses IX and gonoplac well distinguished, anal tube long, with arched side lobes; male pygofer tubular, slightly longer than wide, genital styles fused, male anal tube subquadrate and long, exceeding apices of genital styles. 


\section{Key to subfamilies of Inoderbidae}

1. Body and appendages covered with filamentous wax, dorsum with numerous wax plates (in females only?) producing copious wax strands, especially long on posterior abdomen, wings not folded over abdomen in repose but held laterally, head narrow, frons with small fastigium at midline, antennae with scape and pedicel much elongate, tegmen slightly longer than body, narrowed to base, transparent, basal cell subtrapezoidal and much elongated, costal area with fewer than 10 transverse veinlets, $\mathrm{CuA}_{1}$ with two terminal branches, clavus closed with acute apex, tornus very short, hind wing much shorter than tegmen, legs covered with numerous long setae. Inoderbinae Shcherbakov et Emeljanov, 2021, stat. nov.

2. Body and appendages not covered with filamentous wax, wings folded tectiform over abdomen in repose, head wide, frons without fastigium, antennae with scape and pedicel slightly elongate, tegmen much longer than body, very large and broad, translucent, basal cell relatively short, triangular, costal area with more than 10 transverse veinlets, $\mathrm{CuA}_{1}$ single, clavus closed with blunt apex, tornus longer, hind wing slightly shorter than tegmen, legs covered with numerous very short setae. Ingensalinae Luo, Song et Szwedo subfam. nov.

Subfamily Ingensalinae Luo, Song et Szwedo subfam. nov.

urn:lsid:zoobank.org:act:09A85EE6-624C-4F80-

B9D2-DE34027E131A

\section{Type genus}

Ingensala Luo, Song et Szwedo gen. nov.; here designated and by monotypy.

Diagnosis. Body and appendages not covered with filamentous wax. Wings hold tectiform over abdomen in repose. Head wide, vertex and frons wider than long, frons short, only visible in ventral view, without fastigium; antennal pedicel barrel-like, with sensory plaque organs. Tegmen much longer than body, very large and broad, about twice as long as wide, translucent, shallowly tectiform, clavus with blunt apex, tornus well developed, basal cell relatively short, triangular; costal area with more than 10 transverse veinlets, $\mathrm{CuA}$ forked at same level of $\mathrm{ScP}+\mathrm{R}$ fork, $\mathrm{CuA}_{1}$ single, $\mathrm{CuP}$ reaching margin at about $3 / 5$ ths of tegminal length, $\mathrm{Pcu}+A_{1}$ reaching claval margin (vein $A_{2}$ ) slightly beyond half of tegminal length. Hind wing slightly shorter than tegmen. Legs carinate, covered with numerous very short setae.

Genus Ingensala Luo, Song et Szwedo gen. nov. (Figs. 1-4)

urn:Isid:zoobank.org:act:C813BB00-005E-406C-

BCCF-079BF1BA223D

\section{Type species}

Ingensala xiai sp. nov.; by present designation and monotypy.

\section{Etymology}

The generic name is derived from the combination of two words from the Latin language: ingens' meaning "huge, vast, enormous" and ala' meaning "wing", referring to the very large tegmen of the genus. Gender: feminine.

\section{Included species}

Type species only.

\section{Diagnosis}

Head with compound eyes about $2 / 3$ times as wide as pronotum, vertex transverse, wider than long in mid line. Lateral margins of frons distinct, carinate, no median carina, lateral carinae of clypeus carinate. Mesonotum with postocular carinae. Tegmen twice about as long as wide, with distinct venation, costal area present, intersected with a few transverse veinlets; costal cell with two transverse veinlets, submarginal "pseudostigma" present near end of costa area; RA with two terminals, RP with four terminals, MP with three terminals, $\mathrm{CuA}$ with six terminals, Cell $\mathrm{C}_{1}$ open, Cell $\mathrm{C}_{3}$ shorter than cell $\mathrm{C}_{5}$. Apical row of veinlets present, arcuate. Male genital styles fused medially.

Age and occurrence. Mid-Cretaceous (early Cenomanian); amber from Kachin State, northern Myanmar.

Ingensala xiai Luo, Song et Szwedo sp. nov.

(Figs. 1-4)

urn:lsid:zoobank.org:act:A5922B96-2532-4454-973EBBCFE7534C1C

\section{Etymology}

The specific name is dedicated to Fangyuan Xia, Director of the Lingpoge Amber Museum in Shanghai, for his contribution to the study of this amber specimen.

\section{Material}

Holotype. Specimen no. BA19006, deposited in the Lingpoge Amber Museum in Shanghai. To avoid any confusion and misunderstanding, all authors declare that the fossil reported in this study was collected before 2016 and was not involved in armed conflict and ethnic strife in Myanmar. This specimen is deposited in a public collection permanently that is always accessible to scientists by contacting the corresponding author, in full compliance with the International Code of Zoological Nomenclature and the instructions of the International Palaeoentomological Society (Ride 

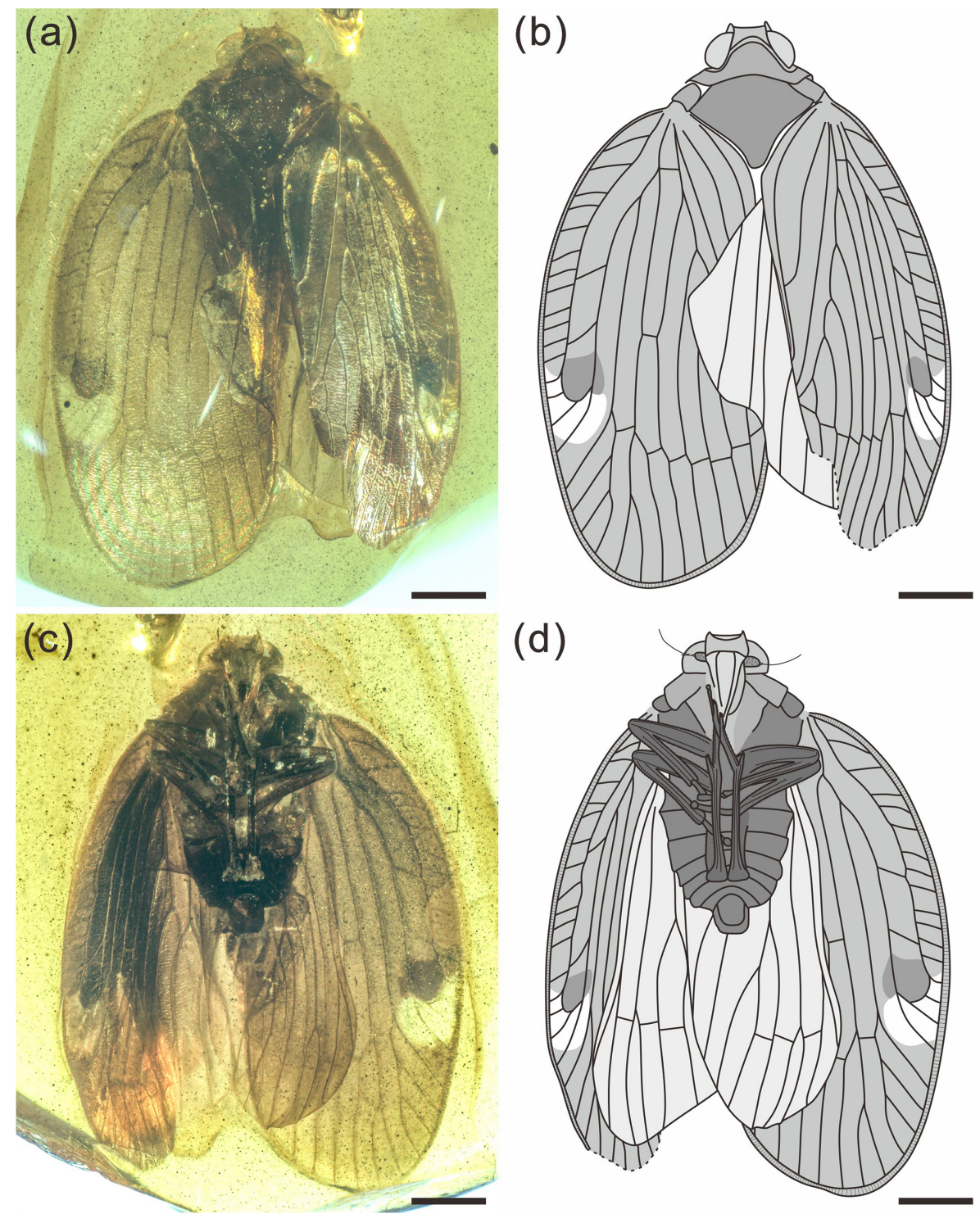

Figure 1. Holotype of Ingensala xiai gen. et sp. nov. (BA19006). (a) Photograph of dorsal view. (b) Line drawing of dorsal view. (c) Photograph of ventral view. (d) Line drawing of ventral view. Scale bars $=1 \mathrm{~mm}$.

et al., 1999; Szwedo et al., 2020). Burmese amber, cabochon, $12 \times 10 \times 5 \mathrm{~mm}$.

Locality and horizon. Kachin amber, near Tanai Village in the Hukawng Valley of northern Myanmar, lower Cenomanian (mid-Cretaceous).

\section{Diagnosis}

Vertex about 4 times wider than long at mid line, trigons absent, frons about 3 times wider than long at mid line. Pronotum almost as wide as mesonotum, mesonotum in mid line 3 times as long as pronotum in mid line. Tegmen basal cell about twice as long as wide, with 12 transverse veinlets in costal area, ScP single, RA with two terminals, RP with four terminals, MP with three terminals, $\mathrm{CuA}$ with six terminals; tegmen with one prenodal mp-cua veinlet, apical row of veinlets arcuate, composed of $r p-m p$ veinlet, two $m p$-cua veinlets, and five icua veinlets; cell $\mathrm{C}_{1}$ longest, cell $\mathrm{C}_{3}$ shortest, cell $\mathrm{C}_{1}$ nearly twice as long as cell $\mathrm{C}_{3}$, cell $\mathrm{C}_{5}$ slightly shorter than cell $\mathrm{C}_{1}$.

\section{Description}

Adult (male). Tegmen uniformly brownish with darker brown "pseudostigma" and larger, semicircular, transparent, light area posteriad of "pseudostigma". Total length ca. $7.2 \mathrm{~mm}$ (wings + body), body $4.2 \mathrm{~mm}$ long (Fig. 1). Head with compound eyes $0.58 \mathrm{~mm}$ long and $1.20 \mathrm{~mm}$ wide, about 2/3 times as wide as pronotum (Fig. 2a). Vertex wider than long, lateral margins converging anteriad, carinate, anterior 

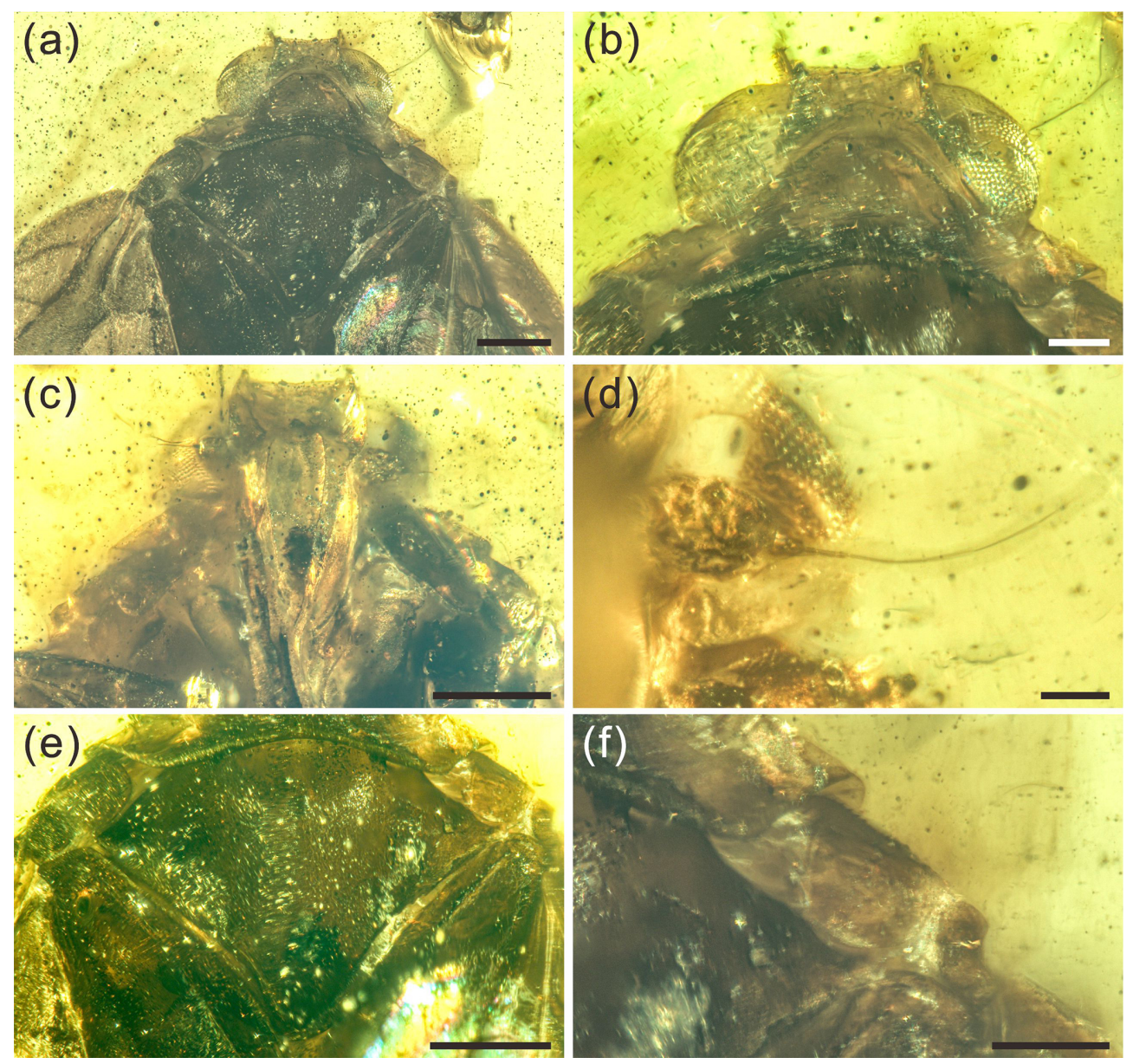

Figure 2. Detailed photographs of the head, pronotum, and mesonotum of Ingensala xiai gen. et sp. nov. (a) Head, pronotum, and mesonotum in dorsal view. (b) Head and pronotum in dorsal view. (c) Head and pronotum in ventral view. (d) Left antenna in ventral view. (e) Mesonotum in dorsal view. (f) Right tegula in dorsal view. Scale bars for $(\mathbf{a}),(\mathbf{c}),(\mathbf{e})=0.5 \mathrm{~mm} ;(\mathbf{b}),(\mathbf{f})=0.2 \mathrm{~mm} ;(\mathbf{d})=0.1 \mathrm{~mm}$.

margin almost straight, posterior margin strongly arched, median carina absent (Fig. 2b). Trigons absent. Frons only visible in ventral view, wider than long, without median carina, converging anteriad; anterior margin curved and posterior margin arched; no fastigium, median carina absent. Frontoclypeal suture slightly arcuate. Clypeus swollen, converging ventrad, with two distinct, subfoliate lateral carinae also converging ventrad (Fig. 2c). Rostrum partly visible, with tip not exceeding metacoxae. Presence of median ocellus and lateral ocelli not confirmed. Antennal scapus longer than wide, pedicel barrel-like with a few sensory plaques visible, $0.22 \mathrm{~mm}$ long and $0.15 \mathrm{~mm}$ wide; flagellum swollen in basal part, whip-like distally, about $0.44 \mathrm{~mm}$ long (Fig. 2d).

Pronotum $0.42 \mathrm{~mm}$ long in mid line and $1.70 \mathrm{~mm}$ wide, saddle-shaped, with disc elevated, postocular carinae distinct, no median carina, anterior margin exceeding level half of compound eyes length, arcuate, posterior margin shallowly arcuate (Fig. 2a, b). Mesonotum $1.22 \mathrm{~mm}$ long and $1.73 \mathrm{~mm}$ wide, slightly convex; with three indistinct, incomplete carinae; no distinct mesoscutellum (Fig. 2a, e).
Tegulae relatively large $(0.40 \mathrm{~mm}$ long and $0.25 \mathrm{~mm}$ wide), carinate (Fig. 2f)

Tegmen (Fig. 3a-f) very large, translucent, with clear dark and pale pterostigma, shallowly tectiform (Fig. 3c). Tegmen broadest near half of its length, about twice as long as wide ( $6.55 \mathrm{~mm}$ long, $3.10 \mathrm{~mm}$ wide at broadest point). Costal area developed. Anterior angle widely arcuate, costal margin arcuate, anteroapical angle widely arcuate, apex rounded, posteroapical angle widely arcuate, shifted slightly basad than anteroapical angle, tornus well developed, straight, not extending beyond line of posterior claval margin Costal margin slightly thickened, appendix narrow, shifting to transversely corrugated appendix from apex of costal area to claval apex; clavus closed with apex blunt, at about $3 / 5$ ths of tegminal length from base. Costal area about as wide as costal cell, reaching level of claval apex, with few transverse veinlets. Basal cell relatively short, triangular, about twice as long as wide $(0.61 \mathrm{~mm}$ long and $0.32 \mathrm{~mm}$ wide at broadest point $)$ (Fig. 3d), basal section of stem $\mathrm{ScP}+\mathrm{R}+\mathrm{M}+\mathrm{CuA}$ slightly thickened. Veins $\mathrm{Pc}+\mathrm{CP}$ subparallel to costal margin (vein 

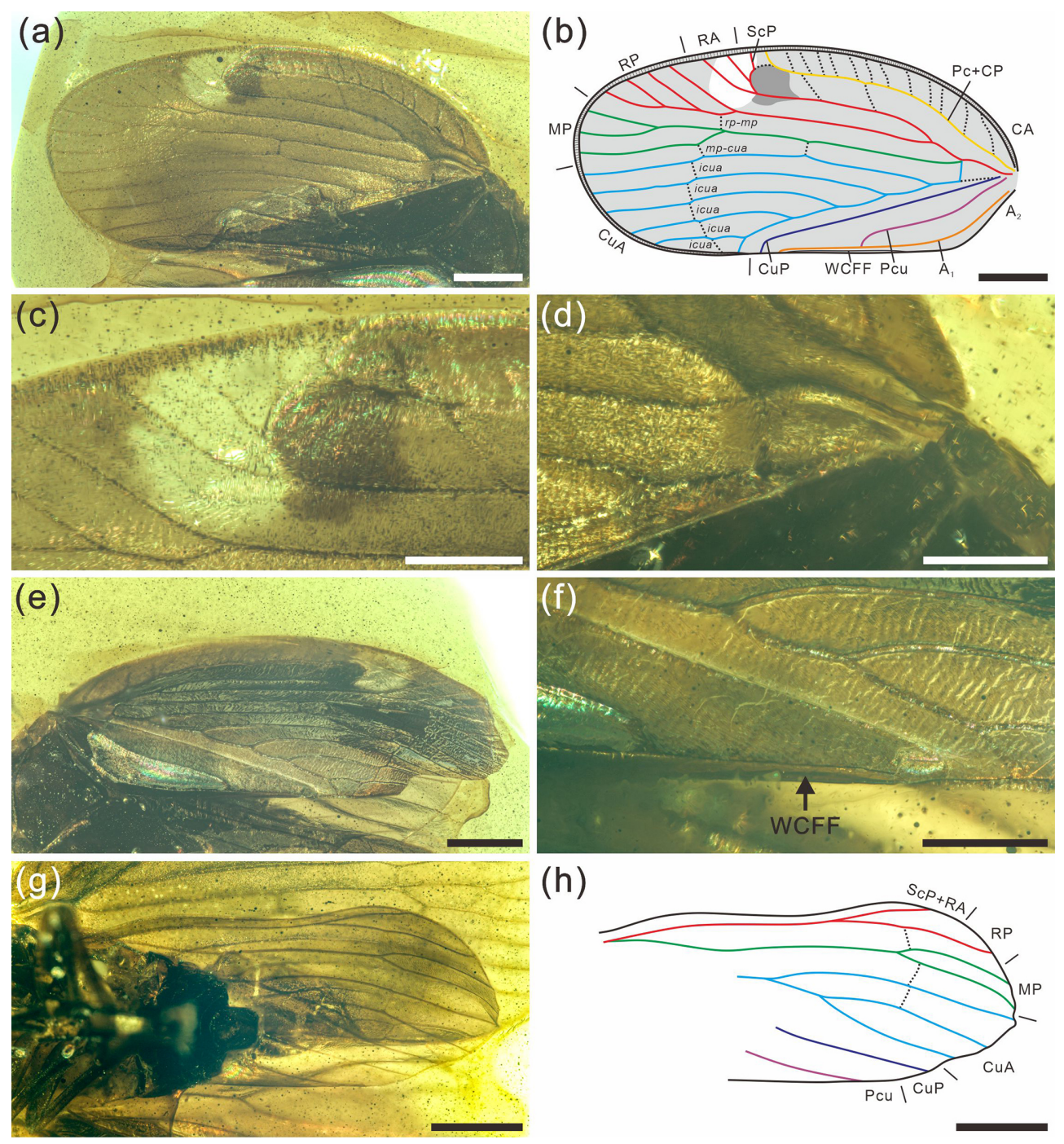

(h)

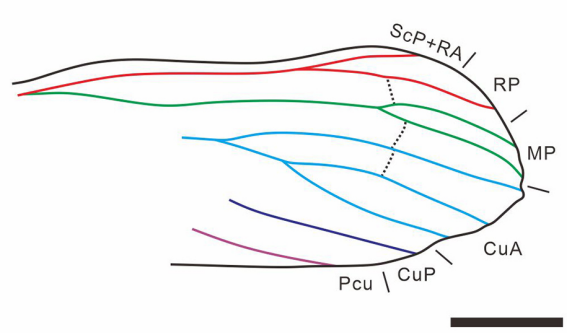

Figure 3. Detailed photographs and line drawing of tegmen and hind wing of Ingensala xiai gen. et sp. nov. (a) Photographs of left tegmen in dorsal view. (b) Line drawing of left tegmen in dorsal view. (c) Pterostigma of left tegmen in dorsal view. (d) Basal part of left tegmen in ventral view. (e) Right tegmen in dorsal view. (f) WCFF of right tegmen in dorsal view. (g) Left hind wing in ventral view. (h) Line drawing of left hind wing in ventral view. Scale bars for (a), (b), (e), (g), (h) $=1 \mathrm{~mm},(\mathbf{c}),(\mathbf{d}),(\mathbf{f})=0.5 \mathrm{~mm}$. Abbreviation: WCFF, wing-coupling fore fold.

CA), reaching margin at about $3 / 5$ ths of tegminal length from base, with 12 transverse veinlets between stem $\mathrm{Pc}+\mathrm{CP}$ and costal margin (vein $\mathrm{CA}$ ). Stems $\mathrm{ScP}+\mathrm{R}$ and MP leaving basal cell at the same point, basal portion of $\mathrm{CuA}$ (arculus) almost perpendicular to base of stem MP. Stems of ScP + RA and RP with a common stalk, slightly shorter than basal cell, then forked at $1 / 3$ of tegminal length from base; branch $\mathrm{ScP}+\mathrm{RA}$ slightly arched, subparallel to stem $\mathrm{Pc}+\mathrm{CP}$, then forked terminally slightly apicad of costal area apex; terminal ScP recurrent; terminals $\mathrm{RA}_{1}$ and $\mathrm{RA}_{2}$ reaching margin basad of anteroapical angle, branch RA reaching margin with two terminals; branch RP branched on membrane, apicad of claval apex, unilaterally branched, with four terminals reaching margin slightly basad of anteroapical angle. Stem MP long, slightly curved at base, then almost straight, subparallel to RP, forked posteriorly, slightly apicad of nodal line, apicad of terminus of costal area and claval apex, at level of line of apical line veinlets; branch $\mathrm{MP}_{1+2}$ slightly arched, then forked again on membrane distinctly apicad of apical line of veinlets, reaching wing margin with two terminals $\left(\mathrm{MP}_{1}\right.$ and $\mathrm{MP}_{2}$ ); branch $\mathrm{MP}_{3+4}$ single, slightly sinuate; three terminals of MP reaching margin at tegmen's apex. The common stalk of stem CuA slightly shorter than basal cell, then forked at basad 1/3 of tegmen's length, at level of $\mathrm{ScP}+\mathrm{R}$ forking; branch $\mathrm{CuA}_{1}$ arched, single; branch $\mathrm{CuA}_{2}$ forked again unilaterally, reaching margin with five terminals; six terminals of $\mathrm{CuA}$ occupying margin from apex to tornus. Claval vein $\mathrm{CuP}$ straight, then bent at apex, making apex of clavus 
blunt, reaching margin at about $3 / 5$ ths of tegminal length. Claval veins Pcu and $A_{1}$ fused slightly apicad of half of claval length; Pcu $+A_{1}$ distinctly shorter (by ca. $1 / 3$ ) than $A_{1}$; Pcu sinuate; $A_{1}$ curved; Pcu $+A_{1}$ slightly sinuate, reaching claval margin (vein $A_{2}$ ) slightly basad of claval apex (Fig. 3e). Wing-coupling fore-fold (WCFF) present, subparallel to postclaval margin, reaching end of Pcu $+A_{1}$ (Fig. 3f). Nodal line absent, apical line single, arcuate. Two prenodal veinlets intersecting costal cell and single prenodal veinlet $m p$-cua present, apical rows of veinlets $p c+c p-s c p, r p$ mp, тр-сиа and ісиа distinctly arcuate. Cell $\mathrm{C} 1$ longest ( $3.95 \mathrm{~mm}$ long and $0.31 \mathrm{~mm}$ wide), open; cell C3 shortest ( $2.16 \mathrm{~mm}$ long and $0.28 \mathrm{~mm}$ wide); cell C5 delimited posteriorly by a transverse veinlet (crossvein) icua, $3.51 \mathrm{~mm}$ long and $0.27 \mathrm{~mm}$ wide. Radial section of terminals well developed, covering twice area of median section, median section very narrow, cubital section the largest, covering nearly half of margin from apex to end of tornus. Third section of costal cell near apex of costal area, $p c+c p-s c p$ and terminal, preforking section of stem $\mathrm{ScP}+\mathrm{R}$ more sclerotized, forming submarginal "pseudostigma".

Hind wing (Fig. 3g, h) membranous, transparent, shorter than tegmen, at least $4.74 \mathrm{~mm}$ long and $1.96 \mathrm{~mm}$ wide. Costal margin sinuate, anteroapical angle broadly rounded, posteroapical angle also rounded, like apical margin. Stem $\mathrm{ScP}+\mathrm{R}$ long, slightly sinuate, subparallel to costal margin, then forked at about $1 / 3$ of hind wing length basad of stem MP forking, slightly apicad of branch $\mathrm{CuA}_{2}$ forking; terminal $\mathrm{ScP}+\mathrm{RA}$ single reaching margin well basad of apex; branch RP also slightly arched, single, reaching margin at anteroapical angle. Stem MP long, slightly sinuate, then forked distinctly apicad of stem $\mathrm{ScP}+\mathrm{R}$ fork, with two terminals $\mathrm{MP}_{1+2}$ and $\mathrm{MP}_{3+4}$ reaching margin slightly apicad of apex. Stem CuA long, partly visible, forked at about half of hind wing length, branch $\mathrm{CuA}_{1}$ single, branch $\mathrm{CuA}_{2}$ forked slightly basad of $\mathrm{ScP}+\mathrm{R}$ forking, with two terminals. Transverse veinlets $r p-m p_{1}+2, m p_{3+4}-c u a_{1}$ and $c u a_{1}-c u a_{2 a}$ present, arranged in line, slightly apicad of stem MP fork.

Proleg (Fig. 4a, b, d, f): procoxa elongate, profemur laterally compressed, carinate, with margins covered with numerous very short setae, at least $1.17 \mathrm{~mm}$ long and $0.27 \mathrm{~mm}$ wide; protibia narrow and long, about as long as profemur, subquadrate in cross section, with margins carinate, and covered with numerous very short setae along margins, $1.14 \mathrm{~mm}$ long and $0.15 \mathrm{~mm}$ wide; protarsomeres partly covered, I $0.17 \mathrm{~mm}$ long, widened towards apex, II $0.15 \mathrm{~mm}$ long, indistinct, III $0.22 \mathrm{~mm}$ long, cylindrical; without distinct claws and arolium. Mesoleg (Fig. 4c-f): mesofemur similar to profemur, flattened, carinate, with margins covered with numerous very short setae, $1.41 \mathrm{~mm}$ long and $0.22 \mathrm{~mm}$ wide; mesotibia slightly longer than protibia, narrow and long, subquadrate in cross section, with margins carinate and covered with numerous very short setae, $1.27 \mathrm{~mm}$ long and $0.18 \mathrm{~mm}$ wide; mesotarsomeres partly covered; without distinct claws and arolium (Fig. 4f). Metaleg (Fig. 4g- j): metafemur compressed laterally, shorter than metatibia, covered with numerous very short setae, more robust than metatibia; metatibia narrow and long, carinate, and covered with numerous very short setae, thinnest near the mid part, then widened towards apex, with at least five apical teeth, lacking lateral armature, $1.71 \mathrm{~mm}$ long and $0.09 \mathrm{~mm}$ wide at thinnest part; basimetatarsomere slightly longer than combined length of mid and apical metatarsomeres, cylindrical, dorsally deeply excavated and widened apicad, with a few (5?) apical teeth, $0.72 \mathrm{~mm}$ long and $0.08 \mathrm{~mm}$ wide near the mid part; midmetatarsomere shorter, about half of basimetatarsomere length, excavated dorsally, widened apicad with a few (5?) apical teeth, $0.52 \mathrm{~mm}$ long and $0.07 \mathrm{~mm}$ wide near the mid part; apical metatarsomere narrow, gradually widened apicad, $0.24 \mathrm{~mm}$ long and $0.03 \mathrm{~mm}$ wide; arolium present, claws not visible.

Abdomen with nine segments, wide, flattened, $2.27 \mathrm{~mm}$ long including terminal, and $1.83 \mathrm{~mm}$ wide at broadest part, pregenital segments gradually contracted; posterior margin of last pregenital segment strongly arched (Fig. 4k). Male pygofer tubular, slightly longer than wide in ventral view $(0.53 \mathrm{~mm}$ long and $0.49 \mathrm{~mm}$ wide), genital styles fused medially, male anal tube subquadrate and long, exceeding apices of genital styles in length (Fig. 4i). Female unknown.

\section{Discussion}

Ingensala gen. nov. can be assigned to Hemiptera according to its piercing-sucking mouthparts and can be attributed to Fulgoromorpha due to structure of head capsule with carinae, antennae positioned below the compound eyes, short basicubital triangle and presence of the metatibio-tarsal pecten, and it can be referred to the superfamily Fulgoroidea based on a combination of the following characters: head capsule with margins carinate, clypeus with lateral carinae; antennal pedicel with lentiform flattened plaque sensory organs and whip-like flagellum, tegulae present, tegmen with narrow appendix transversely wrinkled and "Y-shape" veins on clavus (fusion of Pcu and $A_{1}$ ). Ingensala gen. nov. can be attributed to the recently established planthopper family Inoderbidae Shcherbakov et Emeljanov, 2021 mainly according to the following characters: lateral margins of vertex and frons foliaceous, vertex and frons without median carina, clypeus with two subfoliate lateral carinae; pronotum without median and lateral carinae, mesonotum without distinct median and lateral carinae and no distinctly separated mesoscutellum; tegmen with submarginal "pterostigma", costal area present, intersected by a few transverse veinlets, MP forked very late, MP area reduced, $\mathrm{CuA}$ forked very early with numerous terminals, cubital area large. Both genera are characteristic of similar size (body $5.8 \mathrm{~mm}$ long in Inoderbe rapunzel Shcherbakov et Emeljanov, 2021, $4.2 \mathrm{~mm}$ in Ingensala xiai gen. et sp. nov.), 

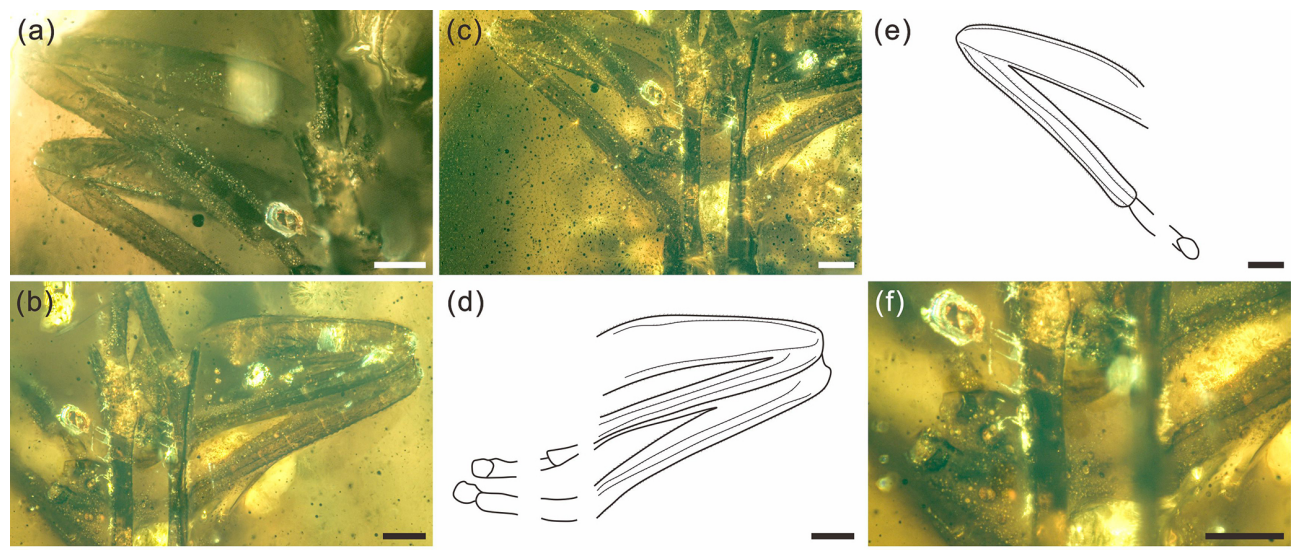

(d)
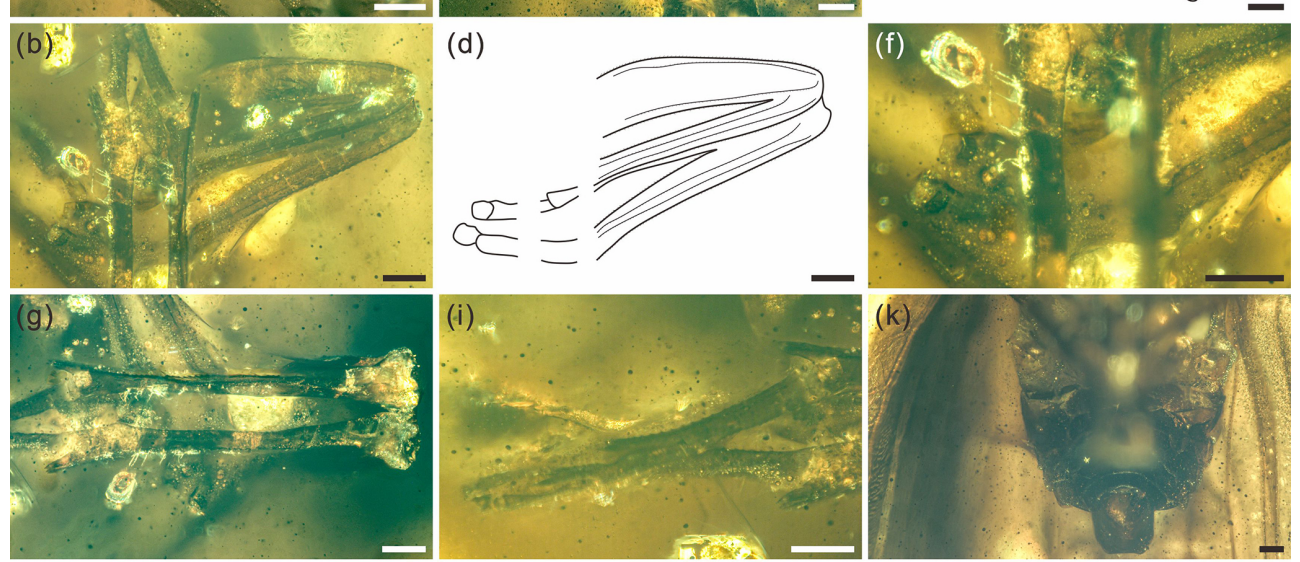

(h)

(j)
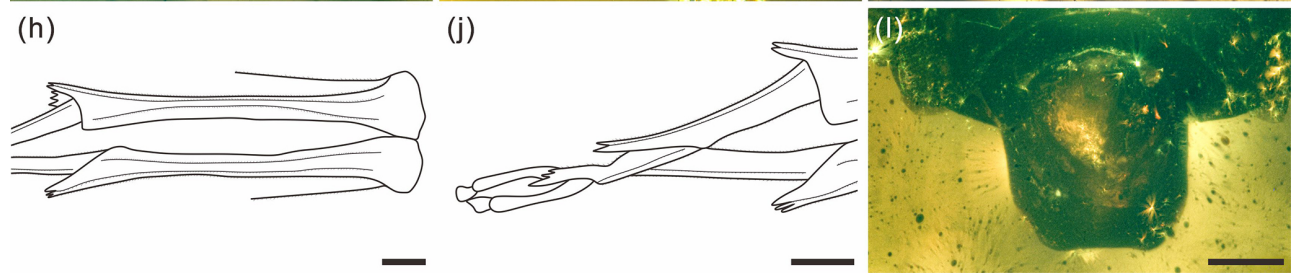

Figure 4. Detailed photographs of legs and abdomen of Ingensala xiai gen. et sp. nov. in ventral view. (a) Right proleg and mesoleg. (b) Left proleg and mesoleg. (c) Right mesoleg. (d) Line drawing of left proleg and mesoleg. (e) Line drawing of right mesoleg. (f) Terminal of left proleg and mesoleg. (g) Metafemur and metatibia. (h) Line drawing of metafemur and metatibia. (i) Terminal of metaleg. (j) Line drawing of terminal of metaleg. (k) Abdomen. (l) Pygofer. Scale bars $=0.2 \mathrm{~mm}$.

Shcherbakov and Emeljanov (2021) have mentioned the tegmen of Inoderbidae is similar to the Early Jurassic genus Eofulgoridium Martynov, 1937, but this similarity is superficial, in Eofulgoridium, the basal cell is not elongate, the submarginal sclerotization ("pseudostigma") is absent, the $\mathrm{CuA}$ is not so richly branched, and hind wings are not so small. However, the tegmen of Ingensala gen. nov. is even more similar to Eofulgoridium rather than the type genus Inoderbe. The similar shape of tegmen (although tegmen is much elongate in Eofulgoridium), triangular basal cell, the costal area with more than 10 transverse veinlets, MP forked late, $\mathrm{CuA}$ forked near the same level of $\mathrm{ScP}+\mathrm{R}$ fork, $\mathrm{CuP}$ reaching margin at about $3 / 5$ ths of tegminal length, Pcu $+A_{1}$ reaching claval margin slightly beyond half of tegminal length are all same features present in both genera, Ingensala and Eofulgoridium, but the colour pattern and numerous transverse veinlets of Eofulgoridium is lacking in Ingensala (as well as in Inoderbe) (Martynov, 1937; Zhang et al., 2003). Shcherbakov and Emeljanov (2021) considered that Inoderbidae might descend from Fulgoridiidae and the discovery of Ingensala gen. nov. further confirmed this view. Another Jurassic planthopper family Qiyangiricaniidae also shares some characters with Inoderbidae like the late fork of stem $\mathrm{MP}$, the early fork of $\mathrm{CuA}$, and the stem $\mathrm{CuA}$ bearing many branches (Szwedo et al., 2011), and these characters might be the plesiomorphy among some ancient planthoppers. The stem CuA bearing many branches and covering a large part of tegminal area can also be found in the Eocene Weiwoboidae (Lin et al., 2010), but the late fork of stem MP, with reduced MP area, and absence of network crossveins of Inoderbidae exclude the close relationship between Inoderbidae and Weiwoboidae. Ingensala gen. nov. also superficially resembles some Tropiduchidae: Tropiduchinae, in presence of costal area, late fork of MP, shape of head, fusion of male genital styles, but clearly differs by much wider developed branching of $\mathrm{CuA}$, elongate metabasitarsomere (feature present in more basal Fulgoroidea, viz. Cixiidae, Delphacidae, Achilidae), lack of lateral spines on metatibia and presence of sclerotized submarginal "pseudostigma". Lack of median carina of frons and clypeus seems to be advanced characters of $I n$ gensala gen. nov., and elevation of frons lateral carinae and clypeus lateral carinae are other advanced characters. Elevated disc of pronotum rather seems to be plesiomorphic conditions, similarly as presence of postocular carinae. Dimin- 
ishing of carinae on mesonotum is quite exceptional among Fulgoroidea, and in case of Ingensala gen. nov. it seems to be apomorphic.

However, Ingensala gen. nov. differs from the type genus Inoderbe Shcherbakov et Emeljanov, 2021 to a large extent. Many important apomorphic characters listed for Inoderbe, e.g. short fastigium (head expansion), specialized antennae, tegmen with narrow basal part and elongated basal cell, shortened hind wings, are not presented in Ingensala. In addition, Inoderbe lacks scutellar grooves as well as scutellar angle of the clavus, and its wax-secreting areas on the dorsal thorax and abdomen indicate that Inoderbe's wings do not fold over abdomen in repose but are held laterally (Shcherbakov and Emeljanov, 2021), while Ingensala is normal in these features, holding tegmina tectiform. Therefore, we decide to establish two new subfamilies (Inoderbinae stat. nov. and Ingensalinae subfam. nov.) for these two genera respectively.

Finding of a new planthopper group gives us new insights into the very important period of formation of modern faunistic complexes at mid-Cretaceous biotic re-organization times. The observed diversification in planthoppers as well as among other insects could be the result of pressure of environmental changes. The Cretaceous has often been described as a period of "warm and equable" climate (Hay, 2016), with the average global temperature near to $18^{\circ} \mathrm{C}$. However, more recent refined work shows that climates during the $79 \mathrm{Myr}$ of the Cretaceous were not quite so unvarying as originally thought (Holz et al., 2015; Huber et al., 2018; Vickers et al., 2019). Larger meridional heat transport by atmospheric and/or oceanic circulation, shaping the mid-Cretaceous "supergreenhouse" period (Hasegawa et al., 2012) inferred the area of Kachin amber formation and deposition in the midCretaceous times. The area is considered to be an island or archipelago, whose combination of topography and climatic challenges could be responsible for magnification of evolutionary rate of planthoppers in this area, resulting in their adaptation and fast diversification.

With more nearly 330 families described, Hemiptera represents the most diversified lineage among all insect orders, even exceeding the megadiverse Coleoptera (Szwedo, 2018). As an important component of Hemiptera, planthoppers also have shown very high morphological diversity, which is probably linked with their successful co-evolution with plants (Li et al., 2017). However, the phylogeny of Fulgoroidea is still poorly understood, and the few molecular analyses (Bourgoin and Campbell, 2002; Urban and Cryan, 2007; Song and Liang, 2013) are difficult to correlate with reliable morphological analyses. The situation is even more challenging with fossils because many significant features cannot be recognized. Our knowledge of the early stages of planthopper evolution is still full of unresolved questions, and Inoderbidae adds more information to know the Cretaceous stage of Fulgoroidea evolution and diversification.

\section{Conclusions}

The second genus (Ingensala gen. nov.) of the recently established planthopper family Inoderbidae is described from mid-Cretaceous Kachin amber. The new genus differs from Inoderbe to a large extent, and two new subfamilies are established for these two genera respectively. Inoderbidae is another peculiar group reported exclusively from Kachin amber at present. The discovery of Ingensala xiai gen. et sp. nov. further confirms that Inoderbidae might descend from Fulgoridiidae and contributes to the taxonomic diversity and morphological disparity of Inoderbidae.

Data availability. The material included in this paper is deposited in the Lingpoge Amber Museum in Shanghai, under the inventory number BA19006.

Author contributions. CL designed the study and drafted the manuscript. ZS, XL, TJ, EAJ, and JS reviewed the manuscript.

Competing interests. The contact author has declared that neither they nor their co-authors have any competing interests.

Disclaimer. Publisher's note: Copernicus Publications remains neutral with regard to jurisdictional claims in published maps and institutional affiliations.

Acknowledgements. This paper was edited by Florian Witzmann and reviewed by Dmitry Shcherbakov and one anonymous referee great thanks are due to them. We also express our sincere thanks to Thierry Bourgoin for his thoughtful comments on the manuscript.

Financial support. This research has been supported by the National Natural Science Foundation of China (grant nos. 42125201, 41688103, and 31970442), the Strategic Priority Research Program of the Chinese Academy of Sciences (XDB26000000), and the Second Tibetan Plateau Scientific Expedition and Research (2019QZKK0706). Edmund A. Jarzembowski and Jacek Szwedo thank the Chinese Academy of Sciences for support under the President's International Fellowship Initiative (PIFI). This is a Leverhulme Fellowship contribution for Edmund A. Jarzembowski and a contribution to IGCP 679.

Review statement. This paper was edited by Florian Witzmann and reviewed by Dmitry Shcherbakov and one anonymous referee. 


\section{References}

Bartlett, C. R., Deitz, L. L., Dmitriev, D. A., Sanborn, A. F., Soulier-Perkins, A., and Wallace, M. S.: The diversity of the true hoppers (Hemiptera: Auchenorrhyncha), in: Insect biodiversity, Science and society, 2, edited by: Foottit, R. G. and Adler, P. H., Wiley-Blackwell, Oxford, 501-590, https://doi.org/10.1002/9781118945582.ch19, 2018.

Bourgoin, T.: FLOW (Fulgoromorpha Lists on the Web): a world knowledge base dedicated to Fulgoromorpha, Version 8, updated: 19 December 2021, available at: https://flow. hemiptera-databases.org/flow/, last access: 20 December 2021.

Bourgoin, T. and Campbell, B. C.: Inferring a phylogeny for Hemiptera: falling into the "autapomorphic trap", in: zugleich Kataloge des OÖ, Landesmuseums, Neue Folge Nr. 176, Denisia 04, 67-82, 2002.

Bourgoin, T. and Szwedo, J.: The "cixiid-like" fossil planthopper families, Bull. Insectol., 61, 107-108, 2008.

Bourgoin, T., Wang, R.-R., Asche, M., Hoch, H., Soulier-Perkins, A., Stroiński, A., Yap, S., and Szwedo, J.: From micropterism to hyperpterism: recognition strategy and standardized homologydriven terminology of the forewing venation patterns in planthoppers (Hemiptera: Fulgoromorpha), Zoomorphology, 134, 63-77, https://doi.org/10.1007/s00435-014-0243-6, 2015.

Emeljanov, A. F. and Shcherbakov, D. E.: The longest-nosed Mesozoic Fulgoroidea (Homoptera): a new family from midCretaceous Burmese amber, Far East. Entomol., 354, 1-14, https://doi.org/10.25221/fee.354.1, 2018.

Evans, J. W.: A natural classification of leaf-hoppers (Jassoidea, Hemiptera). Part 1. External morphology and systematic position, T. Roy. Entomol. Soc. London, 96, 47-60, https://doi.org/10.1111/j.1365-2311.1946.tb00442.x, 1946.

Genise, J. F., Bellosi, E. S., Sarzetti, L. C., Krause, J. M., Dinghi, P. A., Sánchez, M. V., Umazano, A. M., Puerta, P., Cantil, L. F., and Jicha, B. R.: 100 Ma sweat bee nests: early and rapid codiversification of crown bees and flowering plants, PLoS ONE, 15, e0227789, https://doi.org/10.1371/journal.pone.0227789, 2020.

Grimaldi, D. A. and Engel, M. S.: Evolution of the insects, Cambridge University Press, Cambridge, ISBN 0-521-82149-5, 2005.

Hamilton, K. G. A.: Insects from the Santana Formation, Lower Cretaceous, of Brazil, Bull. Am. Mus. Nat. Hist., 195, 82-122, 1990.

Hasegawa, H., Tada, R., Jiang, X., Suganuma, Y., Imsamut, S., Charusiri, P., Ichinnorov, N., and Khand, Y.: Drastic shrinking of the Hadley circulation during the mid-Cretaceous Supergreenhouse, Clim. Past, 8, 1323-1337, https://doi.org/10.5194/cp-81323-2012, 2012.

Hay, W. W.: Toward understanding Cretaceous climate An updated review, Sci. China Earth Sci., 60, 5-19, https://doi.org/10.1007/s11430-016-0095-9, 2016.

Holz, M.: Mesozoic paleogeography and paleoclimates - a discussion of the diverse greenhouse and hothouse conditions of an alien world, J. South Am. Earth Sci., 61, 91-107, https://doi.org/10.1016/j.jsames.2015.01.001, 2015.

Huber, B. T., Macleod, K. G., Watkins, D. K., and Coffin, M. F.: The rise and fall of the Cretaceous Hot Greenhouse climate, Glob. Planet Change, 167, 1-23, https://doi.org/10.1016/j.gloplacha.2018.04.004, 2018.
Jiang, T., Szwedo, J., and Wang, B.: A unique camouflaged mimarachnid planthopper from mid-Cretaceous Burmese amber, Sci. Rep., 9, 1-11, https://doi.org/10.1038/s41598-019-49414-4, 2019.

Kania, I., Wang, B., and Szwedo, J.: Dicranoptycha Osten Sacken, 1860 (Diptera, Limoniidae) from the earliest Cenomanian Burmese amber, Cretaceous Res., 52, 522-530, https://doi.org/10.1016/j.cretres.2014.03.002, 2015.

Latreille, P. A.: Genera crustaceorum et insectorum secundum ordinem naturalem in familias disposita, iconibus exemplisque plurimis explicata, edited by: Koenig, A., Parisiis et Argentorati, 1807.

Li, H., Leavengood, J. M., Chapman, E. G., Burkhardt, D., Song, F., Jiang, P., Liu, J., Zhou, X., and Cai, W.: Mitochondrial phylogenomics of Hemiptera reveals adaptive innovations driving the diversification of true bugs, Proc. R. Soc. B, 284, 20171223, https://doi.org/10.1098/rspb.2017.1223, 2017.

Lin, Q., Szwedo, J., Huang, D., and Stroiński, A.: Weiwoboidae fam. nov. of 'higher' Fulgoroidea (Hemiptera: Fulgoromorpha) from the Eocene deposits of Yunnan, China, Acta Geol. Sin.Engl., 84, 751-755, 2010.

Linnaeus, C.: Systema Naturae, Editio Decima, reformata, 1758.

Lloyd, G. T., Davis, K. E., Pisani, D., Tarver, J. E., Ruta, M., Sakamoto, M., Hone, D. W. E., Jennings, R., and Benton, M. J.: Dinosaurs and the Cretaceous terrestrial revolution, Proc. R. Soc. B-Biol. Sci., 275, 2483-2490, https://doi.org/10.1098/rspb.2008.0715, 2008.

Luo, C., Jiang, T., Szwedo, J., Wang, B., and Xiao, C.: A new planthopper family Katlasidae fam. nov. (Hemiptera: Fulgoromorpha: Fulgoroidea) from midCretaceous Kachin amber, Cretaceous Res., 115, 104532, https://doi.org/10.1016/j.cretres.2020.104532, 2020.

Martynov, A. V.: Permian fossil insects from Arkhangelsk District. Part.5. Homoptera, Trudy Paleontol. Inst. Akad. Na. SSSR, 4, 1-35, 1935.

Martynov, A. V.: Liassovye nasekomye Shuraba i Kizil-Kii (Liassic insects from Shurab and Kisyl-Kiya), Trudy Paleontol. Inst. Akad. Na. SSSR, 7, 1-231, 1937.

Peris, D., Labandeira, C. C., Barrón, E., Delclòs, X., Rust, J., and Wang, B.: Generalist pollen-feeding beetles during the mid-Cretaceous, iScience, 23, 100913, https://doi.org/10.1016/j.isci.2020.100913, 2020.

Ride, W. D. L., Cogger, H. G., Dupuis, C., Kraus, O., Mineli, A., Thompson, F. C., and Tubbs, P. K.: International code of zoological nomenclature, International Commission on Zoological Nomenclature, The Natural History Museum, London, UK, ISBN 0-853-01006-4, 1999.

Ross, A. J.: Supplement to the Burmese (Myanmar) amber checklist and bibliography, 2020, Palaeoentomology, 4, 57-76, https://doi.org/10.11646/palaeoentomology.4.1.11, 2021.

Shcherbakov, D. E.: Permian faunas of Homoptera (Hemiptera) in relation to phytogeography and the Permo-Triassic crisis, Paleontol. Zhurn., 34, S251-S267, 2000.

Shcherbakov, D. E.: On Permian and Mesozoic Fulgoroidea, Third European Hemiptera Congress, St. Petersburg, 2004, 68-70, 2004.

Shcherbakov, D. E.: Mesozoic spider mimics - Cretaceous Mimarachnidae fam. n. (Homoptera: Fulgoroidea), Russ. Entomol. J., 16, 259-264, 2007a. 
Shcherbakov, D. E.: An extraordinary new family of Cretaceous planthoppers (Homoptera: Fulgoroidea), Russ. Entomol. J., 16, 139-154, 2007b.

Shcherbakov, D. E. and Emeljanov, A. F.: Paradoxical derbidlike planthopper (Homoptera: Fulgoroidea) from Cretaceous Burmese amber, Russ. Entomol. J., 30, 135-139, https://doi.org/10.15298/rusentj.30.2.03, 2021.

Shi, G., Grimaldi, D. A., Harlow, G. E., Wang, J., Wang, J., Yang, M., Lei, W., Li, Q., and Li, X.: Age constraint on Burmese amber based on U-Pb dating of zircons, Cretaceous Res., 37, 155-163, https://doi.org/10.1016/j.cretres.2012.03.014, 2012.

Song, N. and Liang, A.-P.: A preliminary molecular phylogeny of planthoppers (Hemiptera: Fulgoroidea) based on nuclear and mitochondrial DNA sequences, PLoS ONE, 8, e58400, https://doi.org/10.1371/journal.pone.0058400, 2013.

Song, Z.-S., Xu, G.-H., Liang, A.-P., Szwedo, J., and Bourgoin, T.: Still greater disparity in basal planthopper lineage: a new planthopper family Yetkhatidae (Hemiptera, Fulgoromorpha, Fulgoroidea) from mid-Cretaceous Myanmar amber, Cretaceous Res., 101, 47-60, https://doi.org/10.1016/j.cretres.2019.03.023, 2019.

Song, Z.-S., Zhang, C.-L., Xi, H.-Y., Szwedo, J., and Bourgoin, T.: First record of adult Dorytocidae - Dorytocus jiaxiaoae Song, Szwedo \& Bourgoin sp. nov. (Hemiptera: Fulgoromorpha: Fulgoroidea) from mid-Cretaceous Kachin amber, Cretaceous Res., 125, 104863, https://doi.org/10.1016/j.cretres.2021.104863, 2021.

Spinola, M.: Essai sur les Fulgorelles, sous tribu de la tribu des cicadaires, ordre des Rhyngotes, Ann. Soc. Entomol. Fr., 8, 133454, 1839.

Stål, C.: Hemiptera Homoptera Latr, Hem. Afr., 4, 1-276, 1866.

Szwedo, J.: Nymphs of a new family Neazoniidae fam. n. (Hemiptera: Fulgoromorpha: Fulgoroidea) from the Lower Cretaceous Lebanese amber, Afr. Invertebr., 48, 127-143, 2007.

Szwedo, J.: Jurassic Fulgoridiidae and roots of Fulgoroidea (Insecta: Hemiptera: Fulgoromorpha), Earth Sci. Front., 17, 222223, 2010.

Szwedo, J.: The unity, diversity and conformity of bugs (Hemiptera) through time, Earth Env. Sci. T. R. So., 107, 109-128, https://doi.org/10.1017/S175569101700038X, 2018.

Szwedo, J. and Nel, A.: The Cretaceous insects: a promising state of the art, Cretaceous Res., 52, 628-630, https://doi.org/10.1016/j.cretres.2014.07.008, 2015.
Szwedo, J., Bourgoin, T., and Lefebvre, F.: Fossil planthoppers (Hemiptera: Fulgoromorpha) of the world. An annotated catalogue with notes on Hemiptera classification, edited by: Szwedo, J., Studio 1, Warszawa, ISBN 83-912236-8-X, 2004.

Szwedo, J., Wang, B., and Zhang, H.: An extraordinary Early Jurassic planthopper from Hunan (China) representing a new family Qiyangiricaniidae fam. nov. (Hemiptera: Fulgoromorpha: Fulgoroidea), Acta Geol. Sin.-Engl., 85, 739-748, 2011.

Szwedo, J., Wang, B., Soszynska-Maj, A., Azar, D., and Ross, A.: International Palaeoentomological Society Statement, Palaeoentomology, 3, 221-222, https://doi.org/10.11646/palaeoentomology.3.3.1, 2020.

Thu, K. and Zaw, K.: Chapter 23 - Gem deposits of Myanmar, Geol. Soc. London Mem., 48, 497-529, https://doi.org/10.1144/m48.23, 2017.

Urban, J. M. and Cryan, J. R.: Evolution of the planthoppers (Insecta: Hemiptera: Fulgoroidea), Mol. Phylogenet. Evol., 42, 556-572, https://doi.org/10.1016/j.ympev.2006.08.009, 2007.

Vickers, M. L., Price, G. D., Jerrett, R. M., Sutton, P., Watkinson, M. P. and Meriel FitzPatrick, M.: The duration and magnitude of Cretaceous cool events: Evidence from the northern high latitudes, GSA Bulletin, 131, 1979-1994, https://doi.org/10.1130/B35074.1, 2019.

Westerweel, J., Roperch, P., Licht, A., Dupont-Nivet, G., Win, Z., Poblete, F., Ruffet, G., Swe, H. H., Thi, M. K., and Aung, D. W.: Burma Terrane part of the Trans-Tethyan arc during collision with India according to palaeomagnetic data, Nat. Geosci., 12, 863-868, https://doi.org/10.1038/s41561-019-0443-2, 2019.

Yu, T. T., Kelly, R., Mu, L., Ross, A., Kennedy, J., Broly, P., Xia, F. Y., Zhang, H. C., Wang, B., and Dilcher, D.: An ammonite trapped in Burmese amber, P. Natl. Acad. Sci. USA, 116, 1134511350, https://doi.org/10.1073/pnas.1821292116, 2019.

Zhang, H., Wang, Q., and Zhang, J.: Some Jurassic homopteran insects from the Junggar Basin, Xinjiang,China, Acta Palaeontol. Sin., 42, 548-551, 2003.

Zhang, Q. Q., Jiang, T., Szwedo J., and Zhang, H. C.: A new family of Triassic planthoppers (Hemiptera: Fulgoromorpha: Fulgoroidea) from the Shaanxi Province of China. Alcheringa: Australas, J. Palaeontol., 45, 86-90, https://doi.org/10.1080/03115518.2021.1919206, 2021.

Zhang, X., Ren, D., and Yao, Y.: A new family Jubisentidae fam. nov. (Hemiptera: Fulgoromorpha: Fulgoroidea) from the mid-Cretaceous Burmese amber, Cretaceous Res., 94, 1-7, https://doi.org/10.1016/j.cretres.2018.10.012, 2019. 